\title{
Penetrating Sharp Object Injury in the Gluteal Region and Small Bowel Perforation Due to Pelvic Penetration: A Case Report
}

\section{Gluteal Bölgede Kesici Delici Alet Yaralanması: Pelvis Nafiziyeti Sonucu İnce Barsak Perferasyonu: Olgu Sunumu}

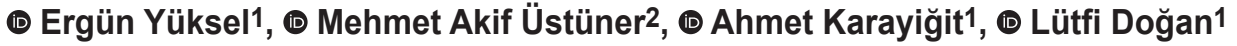 \\ 1 University of Health Sciences, Dr. Abdurrahman Yurtaslan Ankara Training and Research Hospital, Department of General Surgery, Ankara, Turkey \\ 2Türkiye Yüksek İhtisas Training and Research Hospital, Clinic of Gastroenterology Surgery, Ankara, Turkey
}

\section{HIIIIIII ABSTRACT}

Penetrating sharp object injuries in the gluteal region are common. However, it is very rare that these injuries lead to perforation of the small bowel by pelvic penetration, which is generally overlooked. As penetration depth increases, there may be life-threatening injuries such as vascular injury, bowel injury and genitourinary injury depending on the localization of injury site. The case report addressed in the present research focuses on a patient who was admitted to the hospital because of a penetrating sharp object injury in the gluteal region.

Keywords: Penetrating sharp object injuries, gluteal region, perforation of the small intestine

\section{|IIIIIIIII ÖZ}

Gluteal bölgedeki kesici delici alet yaralanmaları sık görülmektedir. Ancak bu yaralanmaların pelvise penetrasyon göstererek ince barsak perforasyonuna sebep olması çok nadirdir. Penetrasyon derinliği arttıkça, yaralanma yerinin lokalizasyonuna bağlı olarak vasküler yaralanma, barsak yaralanması, genitoüriner yaralanma gibi hayatı tehdit eden yaralanmalar olabilir. Bu olgu sunumunda hastaneye gluteal bölgeye kesici delici alet yaralanmasıyla başvuran olgumuzu sunduk.

Anahtar Kelimeler: Kesici delici alet yaralanması, gluteal bölge, ince barsak perferasyonu

\section{Introduction}

The gluteal region is anatomically located between iliac wings, inferior gluteal folds and bilateral greater trochanter. ${ }^{1}$ Penetrating sharp object injuries (PSOIs) in the gluteal region are rare and constitute $2-3 \%$ of all injuries. ${ }^{2}$ These injuries generally do not pose serious health problems. However, visceral and vascular injuries leading to life-threatening events can be observed in one-quarter of the cases. ${ }^{3}$ To the best of our knowledge, little research has been conducted on visceral and vascular injuries in the gluteal region. In this study, we present a case of small bowel perforation arising from an injury in the gluteal region. We hope our study will bring more interest to the subject and contribute to the scarce literature.

\section{Case Report}

A 24-year-old male patient was admitted to the Emergency Department of Dr. Abdurrahman Yurtaslan Ankara Oncology Training and Research Hospital with a PSOI in the gluteal region. Physical examination of the patient revealed $1 \mathrm{~cm}$ incision in the superior zone of the left gluteal region at 10 o'clock and eviscerated gangrenous ileum loop in the superior zone of the right gluteal region at 9 o'clock (Figure 1). The vitals were stable. A urinary bladder catheter was inserted and

Address for Correspondence/Yazışma Adresi: Mehmet Akif Üstüner MD, 
no macroscopic hemorrhage was observed. Lower extremity peripheral pulses were normal by palpation on both sides. There was no motor deficit in both lower extremities. No abnormality was found in the digital rectal examination.

Abdominal examination revealed muscular guarding and rebound tenderness. Abdominal examination findings and gangrenous prolapse of the ileal segment mandated surgical intervention. Laparotomy was performed via a midline abdominal infraumbilical incision. At exploration,

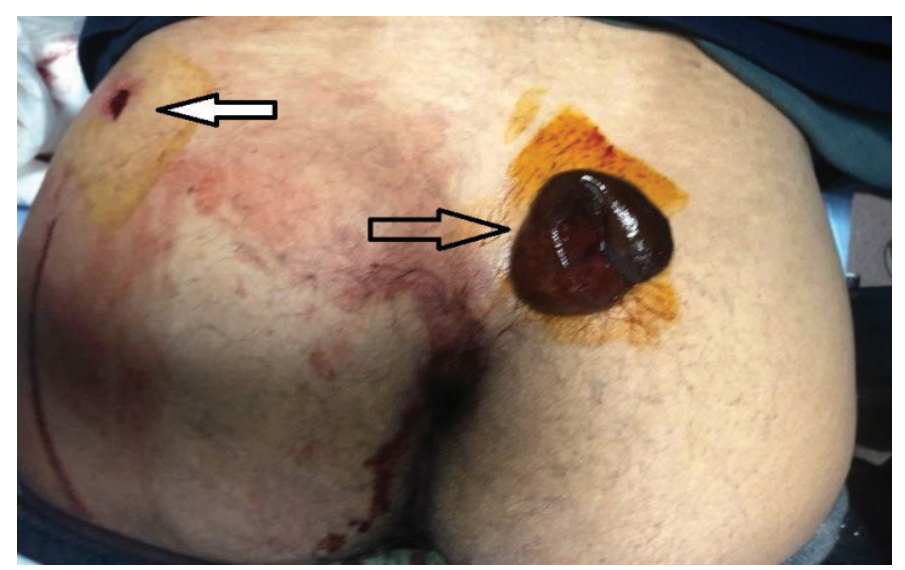

Figure 1. A $1 \mathrm{~cm}$ penetrating injury in the superior zone of the left gluteal region at 10 o'clock; eviscerated gangrenous ileum loop in the superior zone of the right gluteal region at 9 o'clock

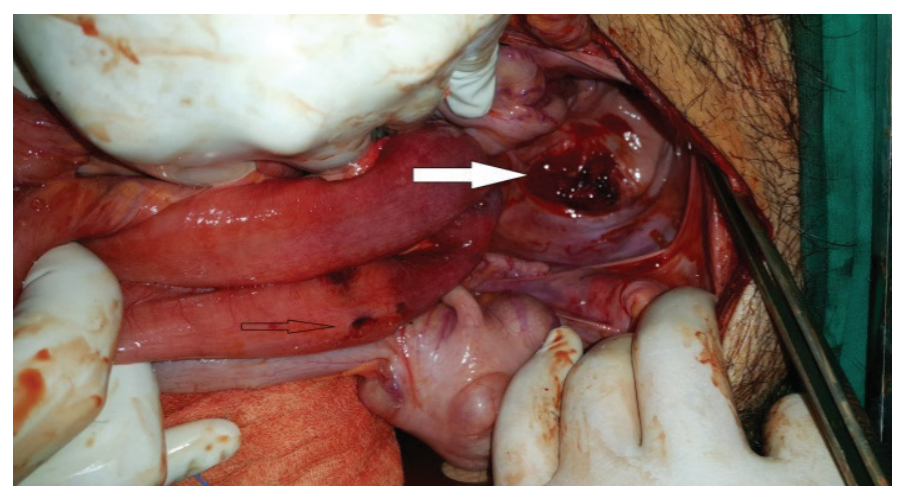

Figure 2. The intestinal loop with 3-4 perforations which was incarcerated through obturator canal which was opened after injury

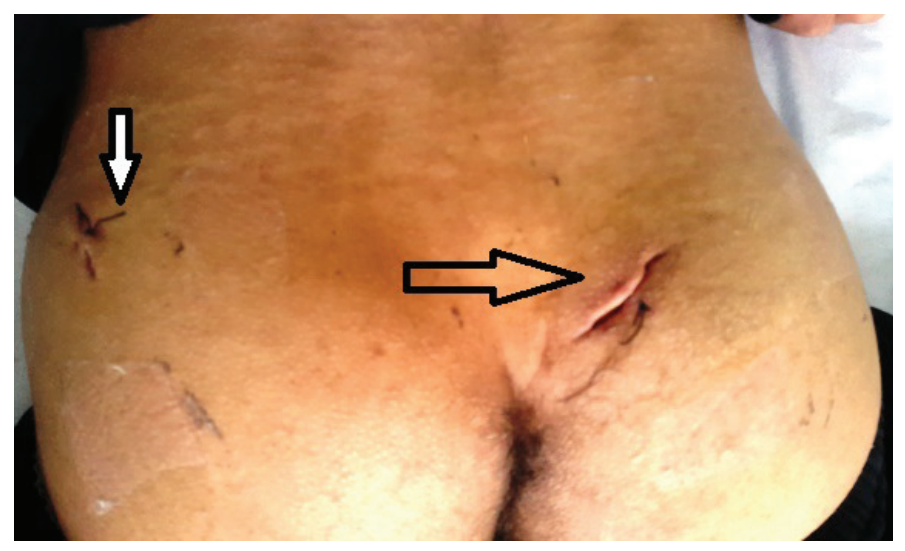

Figure 3. Postoperative gluteal injury sites approximately $200 \mathrm{cc}$ hemorrhagic fluid was present in the abdomen. It was observed that approximately $15 \mathrm{~cm}$ incarcerated small intestinal loop, $20 \mathrm{~cm}$ proximal to the ileocaecal valve, had slipped out through the penetrated obturator canal during the injury. The incarcerated intestinal loop was taken back into the abdominal cavity, and three perforated areas and necrosis were observed (Figure 2). The injured segment was resected and end-to-end anastomosis was performed.

In further exploration, no injury was detected to the iliac, femoral and obturator arteries or veins, aorta and vena cava inferior. The urinary bladder and ureter were intact. After rectal tube placement, it was concluded that the rectum was not injured. The abdominal cavity was irrigated with copious isotonic fluid. The peritoneum in the injured area was debrided and repaired. A drain was placed in the right pararectal space. The injured areas in the gluteal region had already been explored preoperatively, and the operation was completed by placing a Penrose drain in both injury sites (Figure 3).

On postoperative day 2, the possibility of a rectal injury was re-evaluated by rectoscopy. No injury was detected. Neurosurgery consultation recommended electromyography to rule out possible sciatic nerve damage and no deficit was detected by EMG. The bowel movements started on postoperative day 2 and he started oral feeding on day 3 . At the end of postoperative day 6 , he was discharged by surgical healing.

\section{Discussion}

PSOIs are as old as the history of humanity. Nowadays, PSOIs occur with the use of different objects in our country and around the world. According to the study conducted by Üstüner et al., ${ }^{4}$ PSOIs are usually performed by young men (16-35 years old), most often in summer, during may and between 12.00-04.00 a.m. Among these injuries, gluteal injuries are the third most common injuries following thoracic and abdominal injuries. ${ }^{5}$ Depending on the type of injury, patients are generally discharged with antibiotics after closure of the wound with primary suture. However, there may be vascular, intestinal, genitourinary and sciatic nerve injuries depending on the depth and trajectory of penetration. ${ }^{6}$ The upper zone and the lower zone are formed when the gluteal region is divided into two from the intertrochanteric line. Mortality and morbidity of the upper zone injuries are higher than the lower zone. ${ }^{3}$ Angiography and surgical intervention may be required for diagnosis and treatment. ${ }^{7}$ In our case, the injury occurred in the upper zone and the patient was operated.

There is no consensus on the treatment algorithm of penetrating injuries to the gluteal region and the 
management is still to be evolved. Treatment begins with $\mathrm{ABCDE}$. First, $\mathrm{CT}$ is performed to investigate the presence of intraperitoneal fluid in patients with shock. If positive, laparotomy is performed and the localization of the bleeding is determined if negative. Packing and angioembolization are performed depending on the bleeding site, and surgery is performed if the bleeding could not be stopped. In patients without shock, CT is also the initial imaging method. Surgery, angioembolization or observation could be preferred according to the observed bleeding and abdominal injuries. $^{2}$

In 2014, Lunevicius et al., ${ }^{8}$ updated the algorithm and recommended evaluation in the following order: general inspection of the patient, controlling the femoral pulse, neurological examination of the lower extremities, examination of urethra and rectum, and then rectoscopy was suggested after the patient became stable. ${ }^{9}$ Radiologists recommend contrast-enhanced rectal CT if there is stil clinical suspicion of rectal injury despite rectoscopy. ${ }^{6}$ There is no standard treatment for pelvic wounds. ${ }^{10}$

In our case, the examination of the rectum, genital organs, femoral and distal pulses were performed. Since there was an incarcerated intestinal loop seen outside of the gluteal region and findings of acute abdomen, the surgery was performed. On the postoperative day 2 , rectum was checked using rectoscopy. In PSOIs, the mortality rate is $0-2 \%$ in the posterior abdomen region, $0-4.4 \%$ in the anterior abdomen region, $2.1 \%$ in the thoraco-abdominal region, and 2.5-5.6\% in the thorax region. The mortality rate in gluteal injuries is $2.9 \%$, which is quite high compared to other parts of the body. ${ }^{2}$

\section{Conclusion}

In conclusion, PSOIs in the gluteal region may lead to life-threatening damages. Small bowel perforation is one of these damages and should be kept in mind though it is rarely observed.

\section{Ethics}

Informed Consent: Informed consent was obtained from the patient.

Peer-review: Externally peer-reviewed.

\section{Authorship Contributions}

Surgical and Medical Practices: E.Y., A.K., Concept: M.A.Ü., Design: M.A.Ü., L.D., Data Collection or Processing: A.K., Analysis or Interpretation: M.A.Ü., L.D., Literature Search: E.Y., Writing: M.A.Ü.

Conflict of Interest: No conflict of interest was declared by the authors.

Financial Disclosure: The authors declared that this study received no financial support.

\section{References}

1. Ivatury RR, Rao PM, Nallathambi M, Gaudino J, Stahl WM. Penetrating gluteal injuries. J Trauma 1982;22:706-709.

2. Lunevicius R, Schulte KM. Analytical review of 664 cases of penetrating buttock trauma. World J Emerge Surg 2011;6:33

3. Mercer DW, Buckman RF Jr, Sood R, Kerr TM, Gelman J. Anatomic considerations in penetrating gluteal wounds. Arch Surg 1992;127:407410

4. Üstüner MA, İlhan E, Yıldırım M, Aykas A, Senlikci A, Değerli V, et al. Penetrating stab wounds to the abdominal wall: retrospective analysis of 131 cases: can the number of unnecessary laparatomies be reduced? Tepecik Eğit Hast Derg 2015;25:143-150

5. Susmallian S, Ezri T, Elis M, Dayan K, Charuzi I, Muggia-Sullam M. Gluteal stab wound is a frequent and potentially dangerous injury. Injury 2005;36:148-150

6. Campion T, Cross S. The spectrum of injuries in buttock stab wounds Clinical Radiology 2017:543-551.

7. Makrin V, Sorene ED, Soffer D, Weinbroum A, Oron D, Kluger Y Stab wounds to the gluteal region: a management strategy. J Trauma 2001;50:707-710

8. Lunevicius R, Lewis D, Ward RG, Chang A, Samalavicius NE, Schulte KM. Penetrating injury to the buttock: an update. Techn Coloproctol 2014;18:981-992

9. Keğin M, Alçiçek S, Er M, Yıldırım E, Uçar N. Ileum Perforation after a Single Gluteal Stab Wound. Jarem 2015;5:125-127.

10. Uğur M, Oruç C, Yıldız İ, Koca YS, Daban U. The role of co-administration of damage control surgery and vacuum-assisted closure in the treatment of perineal wounds. Turk J Surg 2018;34:229-230. 